\title{
A Comparative Analysis of the EU-Morocco FTA vs. Multilateral Liberalization
}

\author{
Aziz Elbehri \\ Economic Research Service, USDA \\ Thomas Hertel \\ Global Trade Analysis Project, Purdue University
}

\begin{abstract}
An applied general equilibrium model with oligopoly and scale economies, based on detailed plant-level data, is used to contrast the impacts of the Morocco-EU free trade area (FTA) to multilateral trade liberalization on Morocco's economy. Simulation results show that the FTA agreement is likely to have adverse effects on Morocco due to: (a) deteriorating terms of trade, (b) reductions in output per firm in industries dominated by scale economies, (c) diversion of imports away from relatively low cost, non-EU suppliers, and (d) potentially adverse effects on the aggregate demand for labor which could exacerbate already high levels of unemployment. We contrast this FTA with a multilateral liberalization scenario along the lines of those proposed under the Doha Development Round and find this to be more beneficial to Morocco, despite the associated income transfer from the EU to Morocco. The difference may be attributed to: (a) lesser terms of trade losses, (b) positive scale effects, (c) non-preferential liberalization of imports into Morocco, and (d) a positive impact on aggregate labor demand and hence unemployment. We conclude that Morocco would be better off pursuing trade liberalization in the multilateral arena.
\end{abstract}

- JEL classification: F12, F14, F15

\footnotetext{
*Corresponding address: Aziz Elbehri, 1800 M Street NW, Room S5203, Washington DC 20036, USA; Tel: +1(202) 694-5291; Fax: +1(202) 694-5823, E-mail: aelbehri@ers.usda.gov. Thomas Hertel, Professor and Executive Director of GTAP Center; Purdue University; 403 West State St. -Krannert Rm. 563. West Lafayette IN 47907, USA; Tel: ?001-765-494-4199, Fax: ?001-765-496-1224, E-mail: hertel@purdue.edu (2006-Center for International Economics, Sejong Institution, All Rights Reserved.
} 
- Keywords: Applied general equilibrium, Market Structure, Trade liberalization, Developing economies, Morocco

\section{Introduction}

Morocco and the European Union (EU) signed an association agreement (henceforth referred to as FTA) in 1996, which entered into effect in March 2000 aiming at establishing a free trade regime by 2012. This Agreement was part of a broader Euro-Mediterranean initiative, the 1996 Barcelona Protocol, in which the European Union negotiated free trade agreements with Southern Mediterranean countries. The association agreement with Morocco reflects the EU's push for reciprocity and results in a partial free trade agreement as it calls for free trade in industrial goods to be phased in over 12 years, but excludes selected agricultural goods. The latter continue to be regulated by existing preferential agreements that allow for low or no tariffs within pre-specified quantities ${ }^{1}$. The FTA effectively translates into a unilateral liberalization of domestic industries by Morocco as the latter already benefit from duty-free access for its exports to the EU due to previous preferential agreements ${ }^{2}$. In return, the EU promised financial assistance to help the Moroccan industries transition to open competition through investment and training. ${ }^{3}$

FTAs between industrial and developing economies are expected to have much deeper economic effects on the latter (Panagariya, 2002). This is because developing countries typically rely more on trade and have smaller and more poorly functioning markets, and hence more sensitive to international competition than industrialized economies. In the case of Morocco, the FTA is expected to affect more than trade patterns, deeply altering its manufacturing structure as well. Since the 1960's, Morocco's industrial sectors have followed a narrow range of specializations, focusing mostly on goods exported to the European market. Moroccan manufacturing activities have also expanded via import substitution in those domestic industries shielded by

\footnotetext{
${ }^{1} \mathrm{~A}$ recent side agreement between the two sides expanded duty-free quantities for some agricultural products exported by Morocco to EU in exchange for preferential access by Morocco to selected food imported from the EU. However, in this paper we are not modeling the quotas imposed on Morocco's agricultural exports to the EU.

${ }^{2}$ Since 1977 there has been a Morocco-EU preferential agreement that allows Morocco's industrial goods to enter the EU duty-free.

${ }^{3}$ The annual financial assistance from EU as part of FTA Agreement averaged 162.7 Million $€$ from 1997 to 2004 (or \$US 182 million using the average nominal exchange rate of 1.118 US dollars to the $€$ ).
} 
high tariffs. In addition, given the lack of functioning competition rules in Morocco, these industries have become dominated by just a few firms, with substantial market power.

The critical role of market structure in the Moroccan economy can be readily gleaned from Table 1 (last column), which shows data from the 1995 manufacturing census $^{4}$. Eight out of 15 two-digit industries show a four-plant concentration (C4) ratio over 70 percent and 12 of them exceed 50 percent. The most concentrated sectors include beverages \& tobacco and sugar processing, while textiles and clothing exhibit relatively low levels of concentration. The third and fourth columns of Table 1 also show that private industrial ownership dominates the ownership shares, with public ownership significant in only three sectors. It is important to note that these

Table 1. Manufacturing and Market Structure Data for Morocco (1995)

\begin{tabular}{|c|c|c|c|c|c|c|c|}
\hline & \multirow{2}{*}{$\begin{array}{l}\text { Gross } \\
\text { Output } \\
(\%)\end{array}$} & \multirow{2}{*}{$\begin{array}{r}\text { Employ- } \\
\text { ment } \\
(\%)\end{array}$} & \multicolumn{2}{|c|}{ Ownership shares: } & \multirow{2}{*}{$\begin{array}{r}\text { Export/ } \\
\text { Gross } \\
\text { output }\end{array}$} & \multirow{2}{*}{$\begin{array}{r}\text { Capital/ } \\
\text { labor } \\
\text { ratio }^{(a)}\end{array}$} & \multirow{2}{*}{$\begin{array}{r}\text { 4-plant } \\
\text { Concentration } \\
\text { Ratio }\end{array}$} \\
\hline & & & $\begin{array}{r}\text { Private } \\
(\%)\end{array}$ & $\begin{array}{r}\text { Public } \\
(\%)\end{array}$ & & & \\
\hline Meat products & 0.03 & 3.75 & 1.00 & 0.00 & 0.55 & 109.25 & 66.43 \\
\hline Vegetable oils \& fat & 4.02 & 2.39 & 0.38 & 0.62 & 0.03 & 106.99 & 87.27 \\
\hline Dair products & 3.29 & 0.26 & 1.00 & 0.00 & 0.04 & 62.78 & 87.65 \\
\hline Sugar & 3.74 & 4.32 & 0.90 & 0.10 & 0.01 & 42.72 & 90.27 \\
\hline Other food products & 18.47 & 10.05 & 0.92 & 0.08 & 0.20 & 71.00 & 32.52 \\
\hline Beverages \& Tobacco & 8.71 & 2.22 & 0.50 & 0.50 & 0.01 & 120.45 & 95.84 \\
\hline Textiles & 9.14 & 17.09 & 0.95 & 0.05 & 0.40 & 59.43 & 36.91 \\
\hline Wearing apparel & 6.86 & 25.75 & 1.00 & 0.00 & 0.84 & 16.10 & 25.67 \\
\hline Wood products & 1.82 & 2.80 & 1.00 & 0.00 & 0.20 & 37.67 & 81.48 \\
\hline Paper \& Publishing & 4.20 & 3.66 & 0.92 & 0.08 & 0.14 & 123.55 & 51.72 \\
\hline Chemical products & 14.23 & 7.87 & 0.33 & 0.67 & 0.31 & 242.14 & 68.39 \\
\hline Metal products & 17.07 & 12.88 & 0.91 & 0.09 & 0.04 & 114.73 & 56.55 \\
\hline Motor vehicles & 3.64 & 2.84 & 0.93 & 0.07 & 0.14 & 77.62 & 86.56 \\
\hline Light manufacturing & 4.70 & 3.98 & 1.00 & 0.00 & 0.15 & 63.41 & 88.52 \\
\hline Other maunfacturing & 0.07 & 0.14 & 1.00 & 0.00 & 0.08 & 21.07 & 93.25 \\
\hline Total & & 100.00 & & & & & \\
\hline
\end{tabular}

Source: Authors' calculations from the 1995 annual manufacturing survey (Moroccan Ministry of Commerce and Industry)

(a) Capital is proxied by the total establishment net social capital worth

\footnotetext{
${ }^{4}$ The 1995 census, collected by the Ministry of Commerce, included 6040 establishments covering 180 4-digit-level industrial activities.

${ }^{5}$ While the four-firm concentration ratio includes total sales and excludes imports, the effect on market power is likely to be ambiguous. Taking imports into account may lower concentration estimates, at the same time imports are made by the leading domestic producers of similar products which would raise the estimates of concentration (de Melo and Urata, 1986). The net effect of the bias could be small.
} 
concentration ratios understate the potential market power exercised by domestic industries, due to the fact that a small number of holding companies own industrial firms accounting for about half of manufacturing value-added (World Bank, 1994) . In light of these facts, it is hardly surprising that there is evidence of collusive pricing behavior, such as market segmentation between firms, exclusive distribution channels as well as open price fixing. There is also evidence of practices to restrict entry (Nasr et al., 1992).

Many analyses of FTAs have employed the assumptions of perfect competition and constant returns to scale. And advocates of FTAs often argue that the gains from such trade agreements will be larger if features of imperfect competition and increasing economies of scale are incorporated in the analysis. However, the theory of trade policy and imperfect competition is by no means conclusive on this point. In fact, it is equally possible that the gains will be smaller (or losses larger) when these features are taken into account.

A more general question is whether such FTAs are good for the developing country partner. Negotiating, implementing and monitoring such agreements are all costly processes, and detract from potential time and money spent on multilateral negotiations. McQueen (2002) concluded that FTAs between the EU and developing countries offer only small welfare gains to developing countries, and that being "broad but shallow" these FTAs are less likely to result in additional dynamic gains. A critical question is how the economic benefits from FTA compare to those from multilateral trade liberalization. The desirability of unilateral versus regional preferential agreements continues to draw attention in the trade literature (Panagariya, 2002, 2003; Bandara and Yu, 2003). In the case of Morocco, a key question is whether the FTA with the European Union will lock Morocco into a narrow band of industrial specialization in a few labor-intensive industries. Morocco has been successful in these sectors in the past, particularly textiles and apparel, but she may have more difficulty replicating this success in the future as EU's trade barriers against Asian competitors fall. In light of these tradeoffs, we also consider the alternative of incremental multilateral liberalization.

In this paper we apply a multi-sector, multi-region AGE model in which firms in imperfectly competitive industries interact oligopolistically. AGE models featuring imperfect competition have not been used as extensively in the developing country context. With few exceptions (Jansen and Madan, 2004), existing work dealing with the role of market structure often has a weak empirical basis (Devarajan and Rodrik, 1988; Brown et al., 1996). However, more commonly it is ignored altogether 
(Cogneau and Tapinos, 1995; Rutherford et al., 1997). This is problematic, given that imperfect competition and economies of scale are likely to be more important in trade policy analysis of developing than of developed countries (Rodrik, 1988; Jansen and Madan, 2004). Undoubtedly, the lack of firm and industry level data has prevented modelers from constructing more empirically satisfying AGE models of developing countries. This study seeks to address these gaps, by using detailed firm level data from the Moroccan manufacturing census to calibrate markups and unrealized scale economies for Morocco.

Another issue we address is the potential impact of the FTA as well as multilateral liberalization on the aggregate demand for labor. This is of the highest priority for Morocco, given the very high rate of unemployment among unskilled workers. Official unemployment estimates for 2004 are 19-20\% in urban centers and $12 \%$ nationally (as rural underemployment is not taken into account). These high unemployment rates are due to various policy-induced rigidities, including labor policies. Unlike most developing countries, Morocco maintains two minimum wages, one for agriculture and a second for non-farm sectors. These are periodically increased in real terms, and typically at a rate higher than labor productivity, so that they continue to be binding (Azzam, 1997). Other labor market features that affect the cost of hiring include: national and sectoral wage bargaining for skilled workers, compulsory social-security coverage and restrictive hiring and firing regulations.

The remainder of the paper is organized as follows. Section 2 provides an overview of Morocco's foreign trade and its close ties to the European Union. Section 3 describes the theoretical framework used in this paper. Section 4 describes the empirical model and our approach to calibration. Section 5 presents the simulation results while section 6 concludes.

\section{Morocco's Foreign Trade Patterns and European Union's Critical Role}

The EU dominates Morocco's foreign trade. In 1997, the EU market accounted for over 71 percent of fruits and vegetables exports from Morocco, and close to 95 percent of clothing (table 2). Manufactured goods are also exported predominantly to the EU. Only minerals (mostly phosphates) and derived chemical products are exported in a greater proportion to non-EU countries. Imports of manufactures to Morocco - mostly intermediate goods and capital equipment, originate primarily from the EU, with sectoral shares ranging from 56 to 90 percent, and an overall 
Table 2. Share of Morocco's exports and imports by partner (1997; percent total)

\begin{tabular}{|c|c|c|c|c|c|c|c|}
\hline & \multicolumn{3}{|c|}{ EXPORTS TO: } & & \multicolumn{3}{|c|}{ IMPORTS FROM: } \\
\hline & $\begin{array}{r}\text { European } \\
\text { Union }\end{array}$ & $\begin{array}{r}\text { Third } \\
\text { countries }\end{array}$ & $\overline{\text { Total }}$ & & $\begin{array}{r}\text { European } \\
\text { Union }\end{array}$ & $\begin{array}{r}\text { Third } \\
\text { countries }\end{array}$ & Total \\
\hline EXPORTS & & & & IMPORTS & & & \\
\hline Fruit \& Veg & 70.8 & 29.2 & 100 & Grains & 44.3 & 55.7 & 100 \\
\hline Minerals & 46.9 & 53.1 & 100 & Sugar & 1.8 & 98.2 & 100 \\
\hline Proc Food & 56 & 44 & 100 & Food products & 73.3 & 26.7 & 100 \\
\hline Textile & 88.1 & 11.9 & 100 & Textiles & 92.2 & 7.8 & 100 \\
\hline Clothing & 94.9 & 5.1 & 100 & Clothing & 93.4 & 6.6 & 100 \\
\hline Wood products & 91.5 & 8.5 & 100 & Wood products & 79.4 & 20.6 & 100 \\
\hline Paper paste & 66.7 & 33.3 & 100 & Paper products & 86.1 & 13.9 & 100 \\
\hline Chemical products & 30.5 & 69.5 & 100 & Chemical products & 71.7 & 28.3 & 100 \\
\hline metal industry & 86.6 & 13.4 & 100 & metal industry & 66.1 & 33.9 & 100 \\
\hline Motor \& vehicles & 100 & 0 & 100 & Motor \& vehicles & 56.5 & 43.5 & 100 \\
\hline Light manufacturing & 80.5 & 19.5 & 100 & Light manufacturing & 83.4 & 16.6 & 100 \\
\hline Other manufacturing & 66.1 & 33.9 & 100 & other manufacturing & 73.1 & 26.9 & 100 \\
\hline Total & 73.3 & 26.7 & 100 & Total & 72.5 & 27.5 & 100 \\
\hline
\end{tabular}

average of $73 \%$ (Table 2).

Morocco's close trading relationship with the European Union has its origins in colonial ties with France but has been reinforced by bilateral preferential trade agreements over the last few decades. The first preferential agreement between Morocco and the EU was concluded in 1969. This provided for duty free access in industrial goods from Morocco while imposing restrictions on Morocco's agricultural exports to the EU in line with the EU's Common Agricultural Policy. This first preferential agreement stimulated investments in selective manufacturing activities, targeting import substitution products for domestic market and labor-intensive products for exports to the EU- particularly clothing. This contributed to a change in Morocco's trade structure. Between 1965 and 1995, the combined export shares of primary agriculture and food products, declined from over 70 percent to less than 25 percent, while the export share of manufactures climbed from less than 10 percent to 70 percent of total exports, in the same period. This structural shift in trade patterns has been significantly affected by the selective preferential access offered by the EU; namely free access to industrial goods, but restrictive access to agriculture and processed food.

A close examination of Moroccan trade patterns over this period reveals that a narrow manufacturing specialization dominated by labor-intensive activities, dictated by the type of preferential access offered by EU. This is illustrated by the pattern of textile and clothing trade between Morocco and the EU over the last 3 decades as shown in Figure 1. This sector has shown the largest expansion of all 
Figure 1. Morocco's Textiles and Clothing trade patterns (1970-1998), Source: GTAP Database version 4.

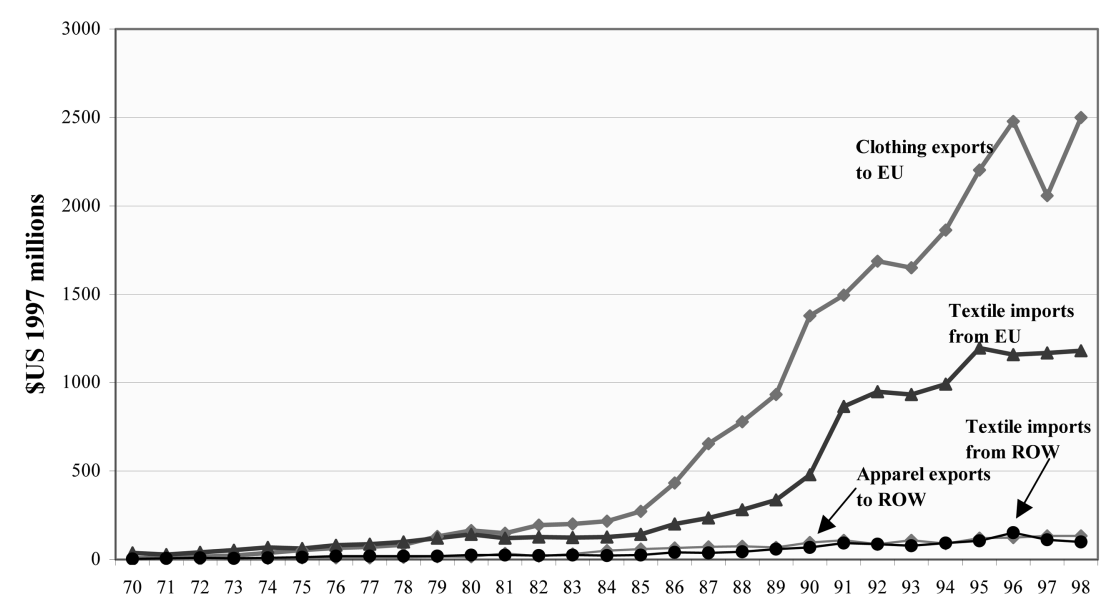

manufacturing industries with export shares to the EU rising from $3.5 \%$ of total value of exports in the early 1970's to $38.7 \%$ in the late 1990 's. Much of the growth in production and trade in textiles and clothing has developed along a close two-way expansion of trade with the EU with very little geographical diversification, as evidenced by the very modest growth in trade with non-EU countries (ROW in Figure 1). The EU preferences, coupled with restrictive rules of origin, played a key role in the clothing sector expansion in Morocco at a time when many of its potential competitors were still under restricted market access. Economic reforms in the 1980's and the gradual opening of the Moroccan economy, have had limited effect on the diversification of production and trade. An exception is the sectors that benefited from the increased importance of vertical international production sharing (Mayer, 2004). This is particularly the case for the manufacturing electronic sector which has grown significantly in the latter part of the1990's and which saw its exports expanding both to the EU and third countries.

In summary, Morocco's heavy-reliance on trade with Europe makes her vulnerable to external shocks from the EU. Moreover, during the 1990's, Morocco has become increasingly sensitive to global competition and the erosion of preferences, as the EU has concluded similar FTAs with third countries. In addition, the removal of the textile and apparel quotas since January 2005 has exposed Morocco to increased competition from Asian suppliers, notably China. These factors have had a negative impact on Morocco's GDP which increased on average by a mere 2.7 percent in the 1990 's, compared to $3.9 \%$ in 1980 's (IMF, 2001). Morocco's 
annual real growth in per capita incomes averaged just $1.4 \%$ over the past decade a figure which is rather low for a developing country with high rates of unemployment. In this context, it is important to ask whether further bilateral liberalization with the EU is the right direction for Morocco's international trade policy to go. As will be shown in the next section this is a complex issue, and the answer cannot be determined solely on the basis of theoretical arguments. Therefore, this paper will address this question empirically.

\section{The Applied General Equilibrium Model}

Empirical analysis of the Morocco-EU FTA is carried out using a modified version of the multi-region applied general equilibrium model, GTAP (Hertel, $1997)^{6}$. The model features imperfect competition and scale economies building on the work of Francois and Roland-Holst (1997) and Francois (1998). However, unlike this earlier work, we also consider the possibility of industry rationalization through the exit of firms from those heavily protected sectors with substantial, unexploited scale economies. Another distinguishing feature of this analysis is that the calibration of oligopoly behavior and scale economies for the Moroccan manufacturing sectors is based on detailed industrial census data. The empirical implementation distinguishes three regions, Morocco, the European Union (EU) and rest of world (ROW). Each economy has 28 sectors, of which 14 refer to manufacturing activity. The latter are characterized by economies of scale and oligopolistic market structures. The remaining sectors encompass agriculture, natural resources, and services activities, and are typified by constant returns to scale in production and perfectly competitive behavior ${ }^{7}$. We next turn to a detailed exposition of the imperfect competition and scale economies features of the model.

\section{A. Scale Economies}

Scale economies for manufacturing sectors are modeled by combining fixed costs with an average variable cost function that is independent of scale. In this

\footnotetext{
${ }^{6}$ The GTAP model is implemented using the GEMPACK software (Harrison and Pearson, 1996). The current version of the model code may be downloaded from the GTAP web site: www.gtap.org.

${ }^{7}$ There are some sectors within the broad service aggregate that are also oligopolistic (e.g., communications). However, these are not taken into account due to problems of aggregation. Also note that the services sector is only indirectly affected by FTA via technical assistance- a side of the agreement that is difficult to quantify.
} 
case, average total cost takes the following form:

$$
A C=\frac{F C}{x}+A V C=\frac{F C}{x}+M C
$$

where: $A C, A V C, M C, F C$ and $x$ are average cost, average variable cost, marginal cost (also invariant to scale), fixed cost, and output per firm, respectively. It is common in the literature (Francois, 1998) to calibrate fixed costs via the cost disadvantage ratio (CDR), which measures the extent to which average total cost exceeds marginal cost:

$$
C D R=\frac{A C(x)-M C(x)}{A C(x)}=\frac{F C}{T C(x)}
$$

With marginal costs that are invariant to scale, the CDR approaches zero asymptotically as output per firm increases ${ }^{8}$.

In this analysis, scale economies are assumed to be internal to the firm and are modeled by linking percentage changes in output with percentage changes in input composite assuming homothetic technologies (Francois, 1998):

$$
\hat{x}=\left[\frac{1}{1-C D R}\right] \hat{Z}=\left[1+\frac{C D R}{1-C D R}\right] \hat{Z}
$$

where $\hat{x}$ and $\hat{Z}$ are percentage changes in output per firm and composite input levels, respectively. The term $1 /(1-\mathrm{CDR})$ is the output elasticity, which also equals the ratio of average to marginal cost (AC/MC).

\section{B. Imperfect Competition}

As noted above, most manufacturing sectors in Morocco are oligopolistic and highly concentrated. There are a wide range of alternative formulations of imperfectly competitive supply behavior in applied general equilibrium models, which, when calibrated to the same data and substitution elasticities have been shown to be rather robust in the wake of trade policy shocks (Willenbockel, 2002). In this paper, we adopt that specification which seems most appropriate to the

\footnotetext{
${ }^{8}$ An alternative method of calibrating scale economies uses the concept of minimum efficiency scale (MES). Besides the high correlation between MES and the Herfindhal index (de Melo and Urata, 1986), the MES measure is based on the assumption of U-shaped long run average cost (LRAC). This is unattractive since the empirical literature supports the L-shaped LRAC curve for which the CDR is more compatible (Johnson, 1960).
} 
Moroccan situation, which is one in which domestic firms produce relatively homogeneous products that are substantially different from the imported European varieties. Given the high degree of concentration in the Moroccan market, we assume that the domestic firms engage in strategic behavior with respect to one another. However, for European firms, the Moroccan market is relatively small, so in the absence of price discrimination, we assume that the prices of these products are independent of the actions of the domestic Moroccan firms.

Formally, the domestic firms are assumed to produce a homogenous good which is exogenously differentiated from those of foreign rivals (the Armington assumption). ${ }^{9}$ Following Francois and Roland-Holst (1997), the elasticity of substitution among imports is assumed to be equal to that between domestic and imported goods (non-nested CES preferences). With respect to domestic rivals, each oligopolist holds the Cournot conjecture (namely that rivals' outputs remain unchanged when the firm varies its own output, with prices adjusting to clear the market). With respect to foreign rival firms, assumed to supply differentiated products, each oligopolist holds a Bertrand conjecture (that is foreign rivals' prices are assumed to remain unchanged in response to a change in their own price $)^{10}$.

Calibration of the Cournot markups is based on the following relationship:

$$
\frac{P-M C}{P}=\left(1-M^{1}\right)=\frac{1}{n \varepsilon}
$$

where $P=$ price, $M C=$ (constant) marginal cost, $M=P / M C=$ the power of the markup over marginal cost, $\varepsilon$ is the market demand elasticity, and $n$ is the Cournot equivalent number of firms. In this equation, the price-markup over marginal costs varies endogenously, decreasing with the number of firms and decreasing with a higher market elasticity of demand.

Francois and Roland-Holst derive the following expression for the market elasticity of demand in the non-nested, CES case, with multiple (global) markets (see also

\footnotetext{
${ }^{9} \mathrm{~A}$ natural alternative to the Armington-type national-level product differentiation specification would be the firm-level product differentiation approach of Dixit and Stiglitz (1977). However, the associated "variety effects", stemming from the entry or exit of domestic firms/varieties would likely dominate the results and we have little basis on which to calibrate these effects. Therefore, we choose to emphasize the role of scale economies and market power.

${ }^{10}$ The approach adopted in this analysis is that proposed by Francois and Roland-Holst (1997). It differs from other formulations of Cournot behavior (e.g., Smith and Venables 1988; Willenbockel, 1994) in which firms are assumed to hold Cournot conjectures about both domestic and foreign rivals.
} 
appendix):

$$
\varepsilon_{s}=\sigma+(1-\sigma) \sum_{r} \frac{X_{r, s}}{X_{r}} S_{r, s}
$$

Here, $\sigma$ is the elasticity of substitution between products from different sources. The ratio $X_{r s} / X_{r}$ is the sales share (i.e., the share of output of commodity $i$-this subscript is suppressed here) originating from region $r$ sold in market $s$. By contrast, $S_{r, s}$ is region $s$ demand share claimed by region $\mathrm{r}$ goods in total purchases of commodity $i$. From this expression, it is clear that the market elasticity of demand is larger, the larger the elasticity of product substitution, and the smaller the sales-share weighted demand market share facing firms in region $\mathrm{r}$. The latter will be small for exportoriented sectors such as wearing apparel (Table 1 shows $84 \%$ of output is exported), since the demand share for Morocco products in foreign markets is quite small. On the other hand, for industries where the elasticity of substitution is small, where the bulk of the sales are to the domestic market (e.g., beverages and tobacco, for which $X_{r r} / X_{r}$ is very high) - and where domestic sales are dominant ( $S_{r, s}$ approaches 1.0) - the second term in equation (5) will be large (and negative) and so the market demand elasticity will be relatively small (see Table 3 ).

As we will see below, it is also of interest to consider the power of the markup over Average Cost:

$$
M_{A}=\frac{P}{A C}=(1-C D R) M C
$$

When this value exceeds one, firms in the sector earn positive profits, as the power of the markup over marginal cost $(M C)$ exceeds the output elasticity, $1 /(1$ CDR). On the other hand, in sectors where the markup is relatively small and the scale effects are strong, it is possible that firms will incur losses in the initial data base. When the product of the power of the markup over marginal cost is precisely equal to the inverse of the output elasticity, we observe zero profits.

\section{Entry and Exit of Firms}

The potential for excess profits or losses raises the question of entry and exit. In this paper, we consider two alternative entry and exit assumptions. In the first case, there is no entry or exit, so non-zero excess profits may arise. In our framework, these profits accrue to the regional household and are spent in the same way as other household income. In the second case, there is entry/exit. However, in order 
to ensure comparability of results between the entry and no entry cases, we avoid implementing a zero pure profits scenario. This would confound the consequences of removing barriers to entry/exit - an issue of industrial policy -- with the direct impacts of trade policy. Therefore, we instead assume no change in the profit margin (defined as profits' share in total revenue) under the entry/exit assumption. Thus if profitability in the beverages and tobacco industry falls as a result of the FTA, we expect that firms will leave the sector until the initial profit margin in the industry is restored.

Since this entry/exit condition departs from previous work in this area (e.g., Francois and Roland-Holst), it is worth deriving it formally and showing what intervening assumptions are implied by our model specification. We begin with the following equation which determines profits per unit of output:

$$
P=A V C+\frac{F C}{x}+\Pi
$$

The combination of the optimal markup and zero profit conditions, (4) and (7), has strong implications for the relationship between the markup and the scale of production in the entry-exit equilibrium. This may be seen most readily by totally differentiating (7), and subtracting $\Omega_{\Pi} \hat{P}$ from both sides, yielding:

$$
\hat{P}-\Omega_{\Pi} \hat{P}=\Omega_{v} A \hat{V} C+\Omega_{F}(\hat{F} C-\hat{x})+\Omega_{\Pi} \hat{\Pi}-\Omega_{\Pi} \hat{P}
$$

where $\Omega_{v}, \Omega_{F}$ and $\Omega_{\Pi}$ are the shares of variable costs, fixed costs, and profits in total revenue and "^" denotes proportional change. This may be rearranged as follows:

$$
\hat{P}=\left[\Omega_{v} A \hat{V} C+\Omega_{F}(\hat{F} C-\hat{x})+\Omega_{\Pi}(\hat{\Pi}-\hat{P})\right] /\left[1-\Omega_{\Pi}\right]
$$

But the change in price is also linked to the optimal power of the markup $(M)$ and marginal costs via (4), so that we must also have:

$$
\hat{P}=\hat{M}+\hat{M} C
$$

Equating (9) and (10), and recognizing that $A V C=M C$ under the assumed (constant) variable cost function, then:

$$
\hat{M}+A \hat{V} C=\left[\Omega_{v} A \hat{V} C+\Omega_{F}(\hat{F} C-\hat{x})+\Omega_{\Pi}(\hat{\Pi}-\hat{P})\right] /\left[1-\Omega_{\Pi}\right]
$$


But we have also assumed a homothetic cost structure, such that the input composition of fixed and variable costs is the same. Therefore, these costs change at the same rate, as a function of factor prices. Thus, $\hat{F} C=A \hat{V} C$ and (11) simplifies, using the fact that the revenue shares sum to one:

$$
\hat{M}+A \hat{V} C=\left[\left(1-\Omega_{\Pi}\right) A \hat{V} C-\Omega_{F} \hat{x}+\Omega_{\Pi}(\hat{\Pi}-\hat{P})\right] /\left[1-\Omega_{\Pi}\right]
$$

Canceling the $A \hat{V C}$ terms from both sides and setting the change in the unit profit rate equal to zero, we have the following fundamental relationship between markups and output per firm in the present of an entry/exit equilibrium:

$$
\hat{M}=\left\{\Omega_{F} /\left[1-\Omega_{\Pi}\right]\right\} \hat{x}
$$

Thus if trade liberalization raises the firms' perceived demand elasticity, and optimal markups fall, then output per firm will increase and there will be positive scale effects. This is precisely the kind of rationalization effect that advocates of FTA's envision, particularly in the case of small economies such as Morocco.

\section{Welfare decomposition: A small country perspective}

To help identify the competing forces at work in determining the small country impacts of an FTA, and to facilitate the analysis of the numerical results, this section provides a brief exposition of the main channels of welfare changes under the FTA using the decomposition proposed by Baldwin and Venables (1995), as well as the implementation of this decomposition in the GTAP model. Baldwin and Venables evaluate the welfare effects of an FTA in terms of the regional household's indirect utility function: $\mathrm{V}(\mathrm{p}, \mathrm{E})$, using the following expression:

$$
d V^{\prime} V_{E}=t \cdot d m-m \cdot d p+[p+t-a] \cdot d X-X \cdot a_{x} \cdot d x+\left[\left(\tilde{r}^{\prime} \rho\right)-1\right] \cdot d I
$$

The first term on the RHS of (14), $t . d m$, represents the trade volume effect whereby net imports $(m)$ are subject to a price wedge created by trade barriers $(t)$, so that changes in imports have first order effects on welfare. This so-called volume of trade effect suggests that trade reform will increase welfare by spurring imports in sectors where domestic prices are kept above world prices. However, following a regional trade agreement, increased imports from the partner country may also accompany an import decline from third countries. Whether trade 
creation or trade diversion dominates, when tariffs or partner country imports are eliminated, will depend on the initial tariff levels, as well as the trade elasticities, used in the model.

The second term in (14), m.dp, represents the "terms-of-trade" effect whereby a decrease in the world price $(d p<0)$ of net imports $(m>0)$ is welfare increasing. The third and fourth terms represent the additional effects which arise in an imperfectly competitive environment. The third term is the "profit-shifting" effect, which measures the welfare impact of changes in industry output $(d X)$ in industries where domestic price $(p+t)$ differs from average cost $(a)$. Ceteris paribus, resource reallocation to sectors in which such excess profits exists is desirable. This creates a potential conflict with the desired outcome from the first term ("trade volume" effect). In the Moroccan case, import-competing sectors are more oligopolistic than the export-oriented ones. Therefore the welfare-improving effects from the first term require that the oligopolistic sectors contract to make room for cheaper imports, whereas the effect from the third term suggests just the opposite - the sectors with the highest profit rates should expand.

The fourth term $\left(X . a_{x} . d x\right)$ is the "scale" effect whereby increased output per firm $(d x>0)$ lowers average cost $\left(a_{x}<0\right)$, thereby reducing the cost of producing total output (X). This term captures the effect of unrealized economies of scale (average cost is higher than marginal cost). This too, leads to a potential conflict with the trade volume effect, since an expansion of average firm output is required for welfare to increase from this "scale" effect, yet output in the import-competing sectors is likely to fall as import volume rises. However, when industry exit is possible, these two effects can be reconciled, since output per firm can increase, even as total industry output falls. This rationalization of industry output may allow for both higher imports (as desired from the volume of trade effects) and expanded output per firm (as desired by the scale effects). This cannot be predicted a priori, which is why a formal model is required.

The last term on the RHS of equation (14) represents the accumulation effect. A change in investment is instantaneously costly, but augments capital stock with social rate of return $\tilde{r}$, which is discounted back to the present at discount rate $\rho$, giving present value $\tilde{r} / \rho$. Change in investment has a first-order welfare effect if this ratio differs from one.

In examining the welfare implications for Morocco from implementing the FTA with the EU, we emphasize the static welfare effects, including the volume-oftrade, profit-shifting, and scale effects. In the absence of information on $\tilde{r} / \rho$, it is 
difficult to say much about the welfare effects of foreign capital inflows following the FTA. So we will focus on the static effects and this aspect of equation (14) will be omitted in the empirical analysis.

On the other hand, our analysis will go further than this simple decomposition on several other fronts. Specifically, we will consider the impact of changes in bilateral imports, as there is considerable potential for diversion of imports from ROW to EU under the FTA. We will also examine the interactions between trade policy and domestic taxes and subsidies, including those adjustments required to maintain revenue neutrality. While these terms - which may be very numerous indeed -- have been omitted from the elegant theoretical decomposition offered in equation (14), they are readily captured in our empirical decomposition, which follows the approach of Huff and Hertel (2001), adapted to handle scale economies and profit shifting via the approach proposed by Francois (1998). In the empirical section below, regional welfare will be measured by Equivalent Variation (EV), which, in turn, will be decomposed into allocative efficiency, terms of trade (term 2 in equation 14), scale economies (term 4 in equation 14) and "labor endowment" effects (the latter is not shown in equation 14, but is easily added and is readily available in the decomposition of Huff and Hertel). The allocative efficiency component includes both the profit shifting (term 3 in equation 14), as well as the trade volume effects (term 1 in equation 14). It also encompasses the interactions between trade and domestic policy taxes or subsidies linked to input use, consumption and tax replacement (not explicitly included in equation 14).

\section{Data and Model Calibration}

The underlying data structure for the model is the global GTAP data base, version 5.3 (Dimaranan and McDougall, 2002). For purposes of this analysis, a Moroccan Social Accounting Matrix for 1990 (Bussolo and Roland-Holst, 1993) was adapted and incorporated into the GTAP data base (Elbehri, 1998).

The 57-sector GTAP database is aggregated into 28 sectors for purposes of this paper. The commodity aggregation is designed to cover the major sectors of importance to Morocco's production and trade. There are 15 manufacturing sectors including six in food processing, with the other 13 covering the agriculture, extractive, and service activities. Manufacturing sectors are disaggregated following the two-digit Moroccan nomenclature of economic activities. The last of the six processed food sectors, "other processed food", includes Morocco's traditional exports of canned 
vegetables, fruits, and fish. Of the eight non-food manufacturing sectors, four are export-oriented industries (clothing, textiles, chemical products, wood products) while the remaining sectors are import substitution industries serving the domestic market (medium and heavy manufacturing, as well as electronics). All 15 manufacturing sectors are treated as oligopolistic with scale economies, while agricultural and service sectors are assumed to be perfectly competitive for purposes of this study. ${ }^{11}$

Calibration of the oligopoly model and scale economies for the manufacturing sectors was based on detailed industrial census ${ }^{12}$ data for 1995 . To calibrate the Cournot model, Herfindhal indices and the model-conformable benchmark number of symmetric firms ${ }^{13}$ were combined with the perceived demand elasticity for each sector to obtain optimal markups via application of equation (4). Table 3 reports the Herfindhal index for each industry, along with the resulting power of the markup over marginal cost. Note the very high markups for processed sugar and beverages and tobacco, with ratios of price to marginal cost of more than two. The smallest markups are for products with a large export share and relatively low concentration indexes: wearing apparel, other food products, and textiles.

Estimation of the cost disadvantage ratio by sector is more problematic. The most common approach to CDR estimates is to compute minimum efficient scale estimates based on engineering cost studies, dating mostly from the 60's and 70's and compiled by Pratten $(1988)^{14}$. However, in addition to being very old, these studies were not conducted in the Moroccan context and are likely to bear little relation to the economic costs and organizational faced there. Therefore, we take a different approach, inspired by de Melo and Urata, (1986). We order the plants for each sector in the manufacturing survey according to gross total plant-level sales.

\footnotetext{
${ }^{11}$ As noted previously, there is evidence of market power in some of the non-manufacturing sectors most notably services. However, we do not have data to support an oligopoly specification in these sectors. Furthermore, the FTA under analysis here does not directly affect these other sectors.

${ }^{12}$ This is a comprehensive annual census covering 6040 firms for 1995 covering all formal sector firms with 10 or more employees or with 100,000 Dirhams (around \$11,000) gross annual revenues. Herfindhal indices for the other regions of the model (EU, ROW) were taken from Haaland and Tellefsen (1994).

${ }^{13}$ This is the number of symmetric firms, which generates the same Herfindhal-Hirschman concentration index as the actual observed asymmetric size distribution in the industry. This approach has been used by Smith and Venables (1988), Willenbockel (1994), and Mercenier (1995).

${ }^{14}$ Examples of analyses include Gasiorek, Smith and Venables (1988); Harrison, Rutherford and Tarr (1994); Roland-Holst, Reniert and Shiells (1994); and Willenbockel (1994).
} 
Table 3. Tariff rates and Market Structure Data for Morocco

\begin{tabular}{|c|c|c|c|c|c|c|c|c|c|}
\hline \multirow[t]{3}{*}{ (percent) } & \multicolumn{4}{|c|}{ Tariff rates } & \multicolumn{5}{|c|}{ Market structure data(b) } \\
\hline & \multirow[t]{2}{*}{ Morocco } & \multicolumn{2}{|c|}{$E U$} & \multirow[t]{2}{*}{ ROW } & \multirow[b]{2}{*}{$\begin{array}{l}\text { Herfindhal } \\
\text { Index (c) }\end{array}$} & \multirow{2}{*}{$\begin{array}{r}\text { Market } \\
\text { demand } \\
\text { elasticity }\end{array}$} & \multirow{2}{*}{$\begin{array}{r}\text { Price- } \\
\text { marginal cost } \\
\text { Markup }^{(d)}\end{array}$} & \multirow{2}{*}{$\begin{array}{r}\text { Price- } \\
\text { average cost } \\
\text { Markup }{ }^{(d)}\end{array}$} & \multirow{2}{*}{$\begin{array}{r}\text { Economies } \\
\text { of scale } \\
(C D R)^{(e)}\end{array}$} \\
\hline & & $\begin{array}{l}\text { From } \\
\text { MOR }^{(a)}\end{array}$ & $\begin{array}{l}\text { From } \\
\text { ROW }\end{array}$ & & & & & & \\
\hline \multicolumn{10}{|l|}{ Primary Agriculture } \\
\hline Grains crops & 28.00 & 53.86 & 52.80 & 34.11 & & & & & \\
\hline Vegetables-fruits & 26.36 & 3.00 & 14.51 & 37.44 & & & & & \\
\hline Oil seeds & 2.50 & 0.00 & 0.00 & 23.22 & & & & & \\
\hline Sugar crops & 17.50 & 251.40 & 251.40 & 82.61 & & & & & \\
\hline Other agriculture & 9.36 & 3.09 & 3.09 & 23.87 & & & & & \\
\hline Livestock & 131.50 & 8.03 & 9.25 & 27.49 & & & & & \\
\hline \multicolumn{10}{|l|}{ Other Primary } \\
\hline Fishing & 33.66 & 12.08 & 4.35 & 3.96 & & & & & \\
\hline Forestry & 8.93 & 0.86 & 0.77 & 1.77 & & & & & \\
\hline Energy products & 23.65 & 2.58 & 0.41 & 5.16 & & & & & \\
\hline Minerals & 7.42 & 0.00 & 0.01 & 3.50 & & & & & \\
\hline \multicolumn{10}{|l|}{ Manufacturing } \\
\hline Meat products & 172.00 & 4.83 & 63.00 & 50.92 & 0.2173 & 4.31 & 1.05 & 0.80 & 0.24 \\
\hline Vegetable oils \& fat & 14.80 & 50.60 & 11.41 & 24.70 & 0.4250 & 3.56 & 1.14 & 0.96 & 0.16 \\
\hline Dair products & 54.34 & 1.27 & 87.68 & 68.45 & 0.4254 & 2.04 & 1.26 & 1.10 & 0.13 \\
\hline Sugar & 148.00 & 7.09 & 76.41 & 20.39 & 0.4893 & 1.70 & 1.41 & 1.26 & 0.11 \\
\hline Other food products & 42.33 & 1.50 & 30.24 & 36.06 & 0.0790 & 1.81 & 1.05 & 0.94 & 0.10 \\
\hline Beverages \& Tobacco & 52.57 & 2.30 & 8.34 & 32.98 & 0.7907 & 1.85 & 1.75 & 1.57 & 0.10 \\
\hline Textiles & 30.21 & 0.00 & 9.08 & 11.97 & 0.1214 & 3.77 & 1.03 & 0.83 & 0.19 \\
\hline Wearing apparel $^{\mathrm{f}}$ & 33.12 & 0.00 & 10.71 & 12.03 & 0.0434 & 3.99 & 1.01 & 1.00 & 0.19 \\
\hline Wood products & 48.88 & 0.00 & 2.62 & 7.83 & 0.3236 & 2.22 & 1.17 & 1.04 & 0.11 \\
\hline Paper \& Publishing & 39.96 & 0.00 & 2.07 & 5.66 & 0.2218 & 1.56 & 1.17 & 0.93 & 0.20 \\
\hline Chemical products & 30.34 & 0.00 & 3.80 & 5.88 & 0.3892 & 2.37 & 1.20 & 1.00 & 0.16 \\
\hline Metal products & 30.79 & 0.00 & 2.60 & 7.51 & 0.2315 & 1.98 & 1.13 & 1.03 & 0.09 \\
\hline Motor vehicles & 26.94 & 0.00 & 5.48 & 8.27 & 0.2867 & 5.31 & 1.06 & 0.79 & 0.25 \\
\hline Light manufacturing & 11.88 & 0.00 & 3.38 & 5.81 & 0.4138 & 4.19 & 1.11 & 0.94 & 0.15 \\
\hline Other maunfacturing & 42.20 & 0.00 & 2.29 & 4.98 & 0.5141 & 2.39 & 1.27 & 1.10 & 0.14 \\
\hline
\end{tabular}

Sources: GTAP data base version 5 ;

(a) Tariff rates from Morocco into EU reflect trade agreements in force between the two partners prior to the FTA.

All manufacturing and market structure data are authors' calculations from annual manufacturing survey (Moroccan Ministry of Commerce and Industry)

(c) Herfindhal indices for the other model regions, EU and ROW (proxied by USA) were taken from Haaland and Tellefsen (1994)

(d) Benchmark price-cost markups were calibrated from a Cournot oligopoly model using Herfindhal indices and perceived demand elasticity. e) Cost disadvantage ratios (CDR) were derived from the Moroccan manufacturing census data

CDR values for EU were taken from Harrison, Rutherford and Tarr (1994) and for ROW (proxied by USA) from Roland-Holst, Reinert and

For wearing apparel we scaled down the power of markup to remove profit losses in the sector which also resulted in zero profits
in aggregate for all manufacturing sectors

We then divide the survey data into two parts, each accounting for one-half of total industry sales. We then compute the ratio of gross output per worker in the smaller firms divided by the corresponding values in the larger firms. This gives us some idea of the potential cost savings due to greater scale of production in each industry. For very large firms, the fixed cost component will be less important and average costs will approach the (assumed constant) marginal cost of output. We use this information to obtain an estimate of the dispersion of CDRs across industries. ${ }^{15}$

\footnotetext{
${ }^{15}$ This measure of scale economies also has limitations in that we assume that differences in output per worker between smaller and larger establishments are due solely to scale economies. A more precise measure would have sorted out the effect of the differences in capital investments between the smaller and larger establishments. However, data limitations precluded such a refinement.
} 
To derive a set of CDRs consistent with the rest of the model, this industry cost ratio is taken as a first estimate of the ratio, $A C / M C$, which is also the output elasticity. This initial estimate is subsequently scaled such that overall profits in manufacturing are equal to zero to obtain the value used in the model. The associated CDRs are also reported in Table 3 . They range from 0.06 in sugar refining, other food products and beverages and tobacco to 0.27 in motor vehicles.

Combining the estimated CDR with the optimal markup over marginal cost, we obtain the markup over average cost using equation (6). This is an estimate of the relative profitability of each sector in our initial data base. Note that the most profitable sector appears to be the highly concentrated beverages and tobacco industry, which faces relatively inelastic market demand and which evidences a relatively low CDR. This is followed by sugar refining and dairy processing. Due to our CDR calibration procedure, which ensures that excess profits in the manufacturing sector as a whole are zero, some industries also show evidence of losses. Meat processing, textiles and motor vehicles, all have relatively small markups while the survey evidence shows rather sizable output elasticities. As a result, there is insufficient revenue to cover fixed costs and estimated per unit profits are negative. ${ }^{16}$ Based on the decomposition in equation (14), expansion of any of the loss-making sectors will contribute to a national overall welfare loss.

\section{Protection, Trade, and Cost Structure Data for Morocco}

The benchmark tariff structure used in the analysis is reported in table 3 . The tariff rates in the version 5.3 GTAP database were updated for Morocco based on the 1996 Moroccan legislation on tariff rates for agricultural goods ${ }^{17}$ and other sources (IMF, 1997; Tangermann, 1997). The database was also adjusted to account for zero tariffs on Moroccan industrial goods exported to the EU using GTAP's “Altertax" feature (Malcom, 1998). Tariffs for processed food products were proportionately adjusted for the content of primary agricultural inputs, since only the non-agricultural components of processed products are imported duty-free into the EU. Table 3 shows that Morocco's tariffs are relatively high compared to

\footnotetext{
${ }^{16}$ Based on this approach, we also estimate substantial losses in Morocco's highly competitive exportoriented apparel sector. This does not seem plausible and the CDR in this sector is revised to give zero profits. This adjustment also ensured that overall profits in Moroccan manufacturing were roughly equal to zero.

${ }^{17}$ Bulletin Officiel Number 4375 bis; Royaume du Maroc; 6 May 1996.
} 
the EU and the rest of the world ${ }^{18}$. With few exceptions, all duties on Moroccan manufacturing imports are higher than ROW and they are much higher than the EU. The exceptions are in food processing industries such as beverage and tobacco products.

In the subsequent sections of this paper, we will examine the impact of the trade agreement between Morocco and the EU that was negotiated in 1996 and began its 12-year implementation period in 2000. This entails removing all tariffs on Morocco's non-food manufacturing imports. In keeping with the EU's approach to trade in processed food products, in the case of manufactured food products, Morocco will eliminate only that portion of the tariffs that protect non-agricultural inputs. Since the EU already offered duty free access to Moroccan imports of manufactured goods, there are no tariff cuts on the EU side, making this tantamount to a unilateral liberalization on Morocco's part. Of course there are other incentives for engaging in this agreement, as noted in the introduction to this paper. We account for these incentives by introducing a lump-sum income transfer from the EU to Morocco as part of the FTA scenario. This is based on an average of observed annual transfers over the 1997-2004 period and equals \$182 million/ year. ${ }^{19}$

\section{Analysis of the EU-Morocco FTA}

Aggregate Welfare Effects of the EU-FTA: The aggregate welfare impacts of the FTA on Morocco are reported in Table 4. The first point to note is that, despite the income transfer from the EU, Morocco loses welfare following this FTA under two of the three closures. The aggregate welfare decomposition in Table 4 explains why Morocco does not generally benefit from the FTA. Begin by considering the no-entry, full employment closure (column 1). When firms do not exit the industry, output per firm falls in almost all of the manufacturing sectors, and this contributes \$US -313.8 million to the aggregate welfare loss. The other argument in the welfare decomposition that relates explicitly to the imperfectly competitive sectors is the profit shifting effect, which is positive ( $\$ 153.9$ million). These can be positive

\footnotetext{
${ }^{18}$ Despite trade liberalization reforms since the mid-1980's, Morocco's trade policies remain restrictive. The un-weighted average MFN tariff rate is 33.9 percent giving Morocco a scale of 8 out of 10 in the IMF's index of trade restrictiveness (IMF, 2001).

${ }^{19}$ In terms of the GTAP model, implementation of this shock involves a positive shock to the incomeslack variable in Morocco, and an (initial income-weighted) offsetting shock to the same variable in the EU.
} 
Table 4. Static Welfare Effects of FTA and Multi-lateral liberalization on Morocco (US 1997 millions)

\begin{tabular}{|c|c|c|c|c|c|c|}
\hline \multirow[b]{3}{*}{ Total welfare } & \multicolumn{3}{|c|}{ FTA scenarios } & \multicolumn{3}{|c|}{ Multilateral liberalization scenarios } \\
\hline & No entry & Entry & $\begin{array}{r}\text { No entry } \\
\text { and Unempl. }\end{array}$ & No entry & Entry & $\begin{array}{r}\text { No entry } \\
\text { and Unempl. }\end{array}$ \\
\hline & -189.5 & 190.2 & -1736.3 & 414.6 & 528.0 & 666.4 \\
\hline Allocative Efficiency & 620.5 & 680.9 & 469.0 & 622.1 & 656.7 & 645.8 \\
\hline Labor Endowment & 0.0 & 0.0 & -1327.1 & 0.0 & 0.0 & 213.8 \\
\hline Scale Economies & -313.8 & 66.1 & -413.1 & -18.7 & 83.1 & -1.7 \\
\hline Terms of trade & -660.3 & -721.7 & -626.6 & -188.7 & -211.8 & -191.5 \\
\hline Transfer from EU* & 164.0 & 164.9 & 161.4 & & & \\
\hline Allocative Efficiency & 620.5 & 680.9 & 469.0 & 622.1 & 656.7 & 645.8 \\
\hline Profit shifting & 153.9 & 130.6 & 178.8 & 8.1 & -8.7 & 5.5 \\
\hline Input tax & -27.7 & -40.7 & -35.0 & -1.5 & -4.8 & -0.2 \\
\hline Consumption tax & -74.1 & -24.9 & -187.0 & 9.6 & 17.8 & 21.1 \\
\hline Export tax & 118.0 & 134.3 & 111.3 & 44.8 & 49.4 & 45.5 \\
\hline Import tax & 450.4 & 481.6 & 401.1 & 561.1 & 603.1 & 573.9 \\
\hline $\begin{array}{l}\text { Aggregate Labor } \\
\text { (percent change) }\end{array}$ & & & -8.4 & & & 1.4 \\
\hline
\end{tabular}

Source: Authors' simulation results

*Impact of EU transfer on welfare depends on GE effects.

if profit-generating oligopolistic sectors expand output, and negative if output contracts. In this scenario, the net effect over all sectors shows a positive profit shifting effect on welfare due to the contraction of the loss making, motor vehicles and parts sector.

Overall, the loss to the Moroccan economy is heavily influenced by the adverse terms of trade (TOT) effect (\$US -660.3 million), which results from the effectively unilateral liberalization being undertaken by Morocco. ${ }^{20}$ In order to offset the surge in imports following the tariff cuts in manufacturing, Morocco must increase her exports. This tends to drive down export prices, provided the EU and ROW do not cut their tariffs. As a consequence, Morocco's TOT deteriorates significantly.

Of course, Morocco could still gain from the FTA if the first term in the welfare decomposition shown in equation (14) - the trade volume effect - were large enough. However, preferential liberalization (EU only) tends to lessen the size of the efficiency gains associated with the import surge. Tariff-preferred imports from the EU are substituted for lower cost products from the ROW, thereby dampening

\footnotetext{
${ }^{20}$ In GTAP terminology, this includes both the terms of trade effects due to merchandise and services trade as well as capital goods.
} 
the gains from displacement of high cost domestic products. Furthermore, the consumption tax increase required to offset the forgone tariff revenue has an adverse impact on efficiency. As a consequence, the net efficiency gains are not large enough to offset the TOT and scale economy losses, and Moroccan welfare falls under the no entry/full employment scenario, even when the income transfer is taken into account. Note also that the effective value to the Moroccan economy of the $\$ 182$ million transfer is somewhat diluted (to \$164 million - last term in the welfare decomposition) in general equilibrium due to interactions with other variables.

When entry/exit is permitted, industry rationalization occurs and output per firm rises in the majority of manufacturing sectors. This gives rise to a positive aggregate scale effect in the welfare decomposition reported in Table 4 (\$66.1 million in column 2 . This is a marked turn-around from the no-entry case, where the scale effect represented a substantial negative contribution to aggregate welfare. On the other hand, the larger increases in exports under the entry/exit case also give rise to larger adverse TOT effects (now \$-721.7 million). Taken together, these largely offset the positive effects of increased scale economies and increased import volumes, and so most of Morocco's $\$ 190$ million welfare gain under the entry/ fixed employment scenario is due to the income transfer effect.

Up to this point, we have not taken into account the high level of unemployment in the Moroccan economy. How will the EU-FTA interact with aggregate labor demand and short term unemployment? For the purposes of this paper, we introduce real wage rigidity into our model closure. Specifically, we postulate a perfectly elastic supply of unskilled labor at the prevailing, fixed real wage rate. We implement this only in conjunction with the no entry case, since real wage rigidity is generally viewed as a short run phenomenon. As can be seen from the aggregate results reported in Table 4, aggregate employment contracts $(-8.4 \%)$ as a result of the EU-FTA, under the unemployment closure. The third column in Table 4 reports the welfare decomposition for the no-entry/unemployment closure. Clearly allowing for a variable supply of unskilled labor in the presence of a fixed real wage has very adverse consequences for the Moroccan economy. The welfare loss is now nearly 10 times as large compared to no entry, full employment case. Most of this additional loss is due to the diminished aggregate demand for labor $(-8.4 \%)$, although the adverse scale effects are quite substantial as well.

Sectoral Effects of the EU-FTA: The impacts of the EU-Morocco FTA on the imperfectly competitive sectors in Morocco are reported in Table 5. The first column of this table reports the change in average market share facing a 
Table 5. Static FTA effects on Morocco's output, markups and trade

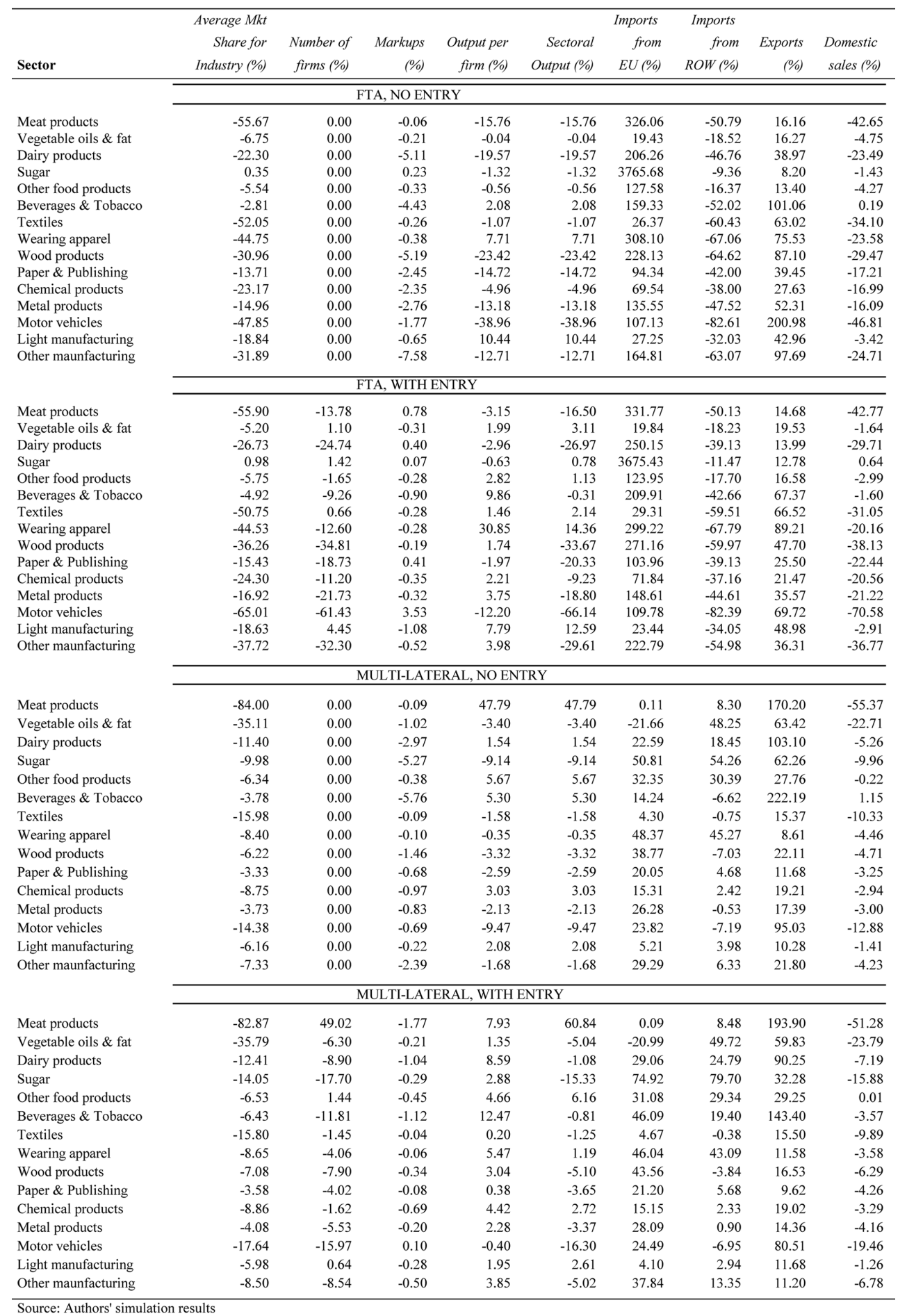


representative firm in each sector. This is the sales share-weighted $\left(X_{r s} / X_{r}\right)$ average of the individual market shares $\left(\mathrm{S}_{r, s}\right.$ term) for the Moroccan firms $(\mathrm{r}=\mathrm{MOR})$ in the domestic ( $\mathrm{s}=\mathrm{MOR}), \mathrm{EU}(\mathrm{s}=\mathrm{EU})$, and ROW ( $=$ ROW) markets that appear in equation (5). Not surprisingly, the Moroccan market share is largest in the domestic market ( $\mathrm{S}_{r, r}$ is large), whereas Moroccan's market share is quite small in the foreign markets. By cutting tariffs, imports erode firms' sales share to this domestic market $\left(X_{r r} / X_{r}\right.$ falls $)$. This is evident from the last column of Table 5. At the same time, the ensuing real devaluation makes Moroccan firms more competi-tive overseas and export sales increase so $\left(X_{r s} / X_{r}\right.$ rises) (see the second to last column of this table). So, with the sale share to the high market share (domestic) market, falling and the sales share to the low market share (export) markets rising, the average market share for Moroccan firms falls in every case but one (sugar). With average market share falling, and a constant number of firms (no entry case), the perceived demand elasticity rises, and optimal markups fall. This is evident in the third column of the FTA, no entry results reported in the top panel of Table 5, where we see the largest declines in the power of the markup over marginal cost in dairy ($5.11 \%)$, beverages and tobacco $(-4.43 \%)$, wood products $(-5.19 \%)$ and other manufacturing $(-7.58 \%)$.

Overall, output (as well as output per firm) falls in most of the manufacturing sectors of Morocco as a result of the EU-FTA under the no-entry scenario. The exceptions are vegetable oils, beverages and tobacco, apparel and light manufacturing. In beverages and tobacco, the decline in markup largely offsets the tariff reduction and leads to a substantial increase in exports. Wearing apparel and light manufactures are export-oriented (Table 1) and the increase in exports following the real depreciation in Morocco dominates the loss in domestic sales.

The next block of results in Table 5 reports the impact of the EU-FTA in the presence of entry/exit. With the possibility of firms leaving the industry, supply response is greater, as are the changes in average market share, which declines as before in all but two cases. The resulting change in perceived demand elasticity also depends, however, on the change in number of firms which is endogenous under this closure. It is possible that the exit of domestic firms could raise markups despite a lower industry average market share. However, this reversal only occurs in the cases of sugar, dairy products, paper and motor vehicles. In general, markups fall by less than in the no-entry case - a direct consequence of the reduction in firm numbers in most sectors.

In the presence of entry/exit, there is an inverse relationship between markups 
and output per firm (recall equation 13). In the ten sectors where markups over marginal cost decline, output per firm increases. This gives rise to increased scale economies in the manufacturing sector as a whole. Sectoral output increases in six sectors in the entry/exit case (compared to four under no entry).

\section{Comparison with Multilateral Trade Liberalization}

Given the close trade ties between Morocco and the EU, and the dependence of Morocco exports on a few key labor-intensive industries (apart from the restricted market access in agriculture), the Morocco-EU FTA doesn't appear to help Morocco diversify its industrial and export bases. Also, the projected efficiency gains from industry rationalization and resource adjustments are not big enough to overcome the substantial TOT losses that arise in the wake of this essentially unilateral liberalization of Morocco's manufacturing trade with the EU. This raises the question: Can Morocco do better under a multi-lateral liberalization option? We explore this option with a simple multi-lateral liberalization scenario that involves a $30 \%$ across the board cut in all tariffs for Morocco, the EU and ROW. This is roughly the magnitude of cuts achieved under the previous multilateral negotiations (the Uruguay Round). It is somewhat more modest than the cuts proposed in the context of recent efforts to restart the Doha Development Agenda negotiations (Josling and Hathaway, 2003). Finally, and important for the comparability of our results, the $30 \%$ cut in tariffs generates roughly the same efficiency gain from increased trade volume as under the EU-FTA. So we can consider these two experiments to be placed on comparable footing in terms of their ability to increase trade volume. The interesting question is then whether the welfare effects of this multilateral approach are substantially different from the bilateral one currently in favor in Morocco.

Aggregate Welfare Effects: Under Multilateral Trade Liberalization (MULTI) aggregate welfare is positive for Morocco under all closure assumptions (table 4, last three columns). The aggregate welfare decomposition reveals additional insights into this general finding. Under the no-entry closure, the combination of output expansion in some sectors and smaller output per firm losses in others, result in negligible scale economy losses overall. This is partially offset by smaller profit shifting gains ( $\$ 8$ million vs. $\$ 154$ million under the FTA), but when combined, the sum of the scale and profit-shifting effects are now roughly zero, as opposed to nearly $-\$ 160$ million in the case of the FTA. Therefore, we conclude 
that multilateral trade liberalization interacts more favorably with Morocco's oligopolistic industry structure than does the EU-FTA.

Turning next to the trade volume effect on welfare, as reported in Table 4; here, we find that the results are quite comparable between the FTA and MULTI experiments, once we sum the import and export tax components of this efficiency effect. While most of Morocco's trade is with the EU and these tariffs are completely eliminated, the FTA-driven efficiency gains are no larger than when all of Morocco's tariffs are cut by just 30\% (MULTI). This is due to the costly diversion of imports away from lower cost ROW suppliers, and towards the EU, as well as the inclusion of agriculture in the MULTI experiment.

The most significant contributing factor to the positive aggregate welfare gain under MULTI is the much smaller TOT losses. In this case the increase in exports required to offset the rise in imports does not lead to lower export prices since the EU and ROW also lower their tariffs, thereby stimulating demand. The net effect is much smaller TOT losses for Morocco compared to the unilateral liberalization under FTA. The overall aggregate welfare gains for Morocco range from $\$ 414$ million to $\$ 666$ million, depending on closures. Note from the consumption tax entry in Table 4 that, even though the consumption tax must still be increased to offset the loss of tariff revenue under MULTI, overall efficiency related to consumption in Morocco rises, due to the increase in aggregate consumption under this scenario.

In contrast, to the EU-FTA, MULTI interacts positively with aggregate labor demand, leading to a $1.4 \%$ increase in aggregate employment. This leads to a further boost in aggregate welfare under the unemployment closure ( $\$ 666$ million vs. $\$ 414$ million in the fixed employment case - see Table 4), beyond that obtained in the no-entry, fixed employment case. As with the EU-FTA, permitting entry/exit increases the welfare gains to Morocco from MULTI, primarily through the rationalization effect, as firms exit the industry, permitting the remaining domestic firms to expand their scale of production.

In summary, not only does MULTI give more of the traditional welfare gains than a comparably-sized EU-FTA, it also interacts positively with two of the major structural features of the Moroccan economy, namely: the high degree of concentration and market power in some of the manufacturing sectors, and the high rate of unemployment amongst unskilled workers.

Sectoral Effects: Under the fixed entry, full employment scenario (third panel of table 5) output (and output per firm) increase in six manufacturing sectors out of 
15. More significantly, many sectors that expand are export-oriented sectors for which Morocco has a comparative advantage. These are food processing, beverages \& tobacco, chemical products and light manufacturing. Under this scenario, wearing apparel shows a slight contraction, as the ROW region displaces Morocco in the EU market. Imports into Morocco now come from both the EU (although at much lower rates of increase than under the FTA), as well as from ROW, which increases sales to Morocco in 10 out of 15 manufacturing sectors (see Table 5).

In the presence of entry and exit, the main difference compared to no-entry case is the wearing apparel that now expands moderately (1.19\%). The other exportoriented sectors also grow, except for beverages and tobacco and dairy products that contract under the entry/exit case. In these highly concentrated sectors, markup reductions are among the highest, and as a result of industry rationalization, the degree of firm exit exceeds the rise of output per firm, resulting in a net decline in sectoral output. In the case of wearing apparel- a comparatively low concentration industry, the extent of firm exit is smaller than the increase in output per firm, resulting in a net rise in sector output under free entry scenario.

\section{Conclusions}

This paper has compared the potential impacts on Morocco's welfare, production and trade, from implementing the Morocco-EU FTA - currently being phased in -- and incremental multilateral liberalization of comparable magnitude. The analysis pays special attention to several key structural features of the Moroccan economy: the highly concentrated industrial sector, the rigid real wage for unskilled labor that has contributed to high levels of unemployment, and the substantial role that tariff revenue plays in the government budget. It also takes account of the foreign aid that Morocco receives as part of their broader, bilateral relationship with the EU. Calibration of the analytical framework's market structure features was based on detailed firm level industrial data using 1995 Moroccan industrial census. This highlights one difficulty in extending this work to other countries - namely the need to obtain detailed industry data.

Results show that the FTA with the EU generates a welfare loss for Morocco in two of the three scenarios examined. When unemployment is ignored, and entry/ exit is permitted, the income transfer to Morocco is sufficient to ensure a positive welfare outcome. Much of the loss arises from substantial TOT losses that 
outweigh the modest gains in resource allocation efficiency. The latter are dampened due to the discriminatory nature of tariff removal under the FTA, as well as the added distortions from the consumption tax for revenue replacement. Most of the manufacturing sectors contract under the FTA and only few export-oriented sectors, such as clothing, expand production. Hence it appears that the main effect of FTA with the EU is to lock the Moroccan manufacturing sector even more firmly into its current pattern of specialization, favoring a few labor-intensive sectors such as wearing and apparel, for which preferential access to the EU market is significant. While this may have been attractive in the past, it appears to be a far less satisfactory strategy today, with international trade barriers continuing to fall, and with Morocco facing the inevitable erosion of its trade preferences in the EU.

The tendency of the EU-Morocco FTA to reinforce historical patterns of production and specialization is particularly troubling in the case of textiles and apparel, where the recent removal of quotas beginning January 2005 has the potential to significantly reduce Moroccan market share in the EU. In this environment, multilateral trade liberalization appears to be much more favorable to Morocco. Not only do the traditional efficiency gains dominate the TOT losses, but this liberalization strategy also interacts in a more positive way with Morocco's highly concentrated industry structure, as well as increasing (as opposed to diminishing) the demand for unskilled labor in Morocco. In summary, Morocco would be well advised to invest more of its energy in helping to obtain a positive outcome in the multilateral trade negotiations.

\section{Acknowledgements}

The authors thank Glenn Harrison for valuable feedback on previous drafts of this paper. Thanks are also extended to Joe Francois and Dirk Willenbockel, as well as anonymous reviewers for helpful comments.

Received 13 September 2005, Accepted 29 May 2006

\section{References}

Azzam, J.P. (1997) Efficiency wage and the family: An Explanation for the impact of the agricultural minimum wage in Morocco, Kyklos Vol. 50 (Fsc. 3): 369-382. 
Baldwin, R.E. and A.J. Venables (1995) Regional Economic Integration, in Handbook of International Economics, volume III, G.M. Grossman and Rogoff, K. (Eds.) (NorthHolland/Elsevier).

Bandara, J.S. and W. Yu (2003) How Desirable is the South Free Trade Area? A Quantitative Economic Assessment, World Economy, 26, 9: 1293-1323.

Brown, D.K., A.V. Deardorff and R.M. Stern (1996) Some Economic Effects of the Free Trade Agreement Between Tunisia and European Union, Prepared for the Egyptian Center for Economic Studies Conference: How Can Egypt Benefit from a Trade Agreement with the EU? (Cairo, Egypt, June 26-27, 1996).

Bussolo M. and D. Roland-Holst (1993) A Detailed Input-Output Table for Morocco, 1990, OECD Technical Paper. No. 90 (OECD, Paris).

Cogneau, D. and G. Tapinos (1995) Libre-echange, repatition du revenu et migrations au Maroc, Revue d'Economie de Developpement, No 1: 28-52.

De Melo, J. and S. Urata (1986) The influence of increased foreign competition on industrial concentration and profitability, International Journal of Industrial Organization 4: 287-304.

Devarajan, S. and D. Rodrik (1989) Trade liberalization in developing countries: Do imperfect competition and scale economies matter?, American Economic Review 79, 283-287.

Dimaranan, B. and R. McDougall (eds.) (2002) Global Trade, Assistance, and Protection: The GTAP 5 Database. West Lafayette, Indiana (Center for Global Trade Analysis, Purdue University).

Dixit, A. K. and J. E. Stiglitz (1977) Monopolistic competition and optimum product diversity, American Economic Review 67, 297-308.

Elbehri, A.(1998) Morocco Input-Output Table,' in Global Trade, Assistance, and Protection: The GTAP 4 Data Base, R.A. McDougall, A. Elbehri and T. Truong (eds.) (1998), Center for Global Trade Analysis, Purdue University.

Francois, J. F. (1998) Scale economies and imperfect competition in the GTAP Model, GTAP Technical Paper No. 14

Francois, J. F. and D. W. Roland-Holst (1997) Scale economies and imperfect competition, in J. Francois and K. Reinert (eds.) Applied Methods for Trade Policy Analysis: A Handbook, New York: Cambridge University Press.

Gasiorek, M., A. Smith and A.J. Venables (1992) 1992: Trade and welfare; a general equilibrium model, CEPR Discussion Paper No. 672 (London: CEPR).

Haaland, J.I. and T.C. Tellfsen (1994) The Uruguay Round and Trade in manufactures and services: General equilibrium simulations of production, trade and welfare effects of liberalization, CEPR Discussion paper No 1008, London.

Harrison, W.J. and Pearson, K.R. (1996) Computing solutions for large general equilibrium models using GEMPACK, Computational Economics 9: 83-127.

Harrison, G.W., T.F. Rutherford and D.G. Tarr (1994) Product standards, imperfect competition and the completion of the market in the European Community, Policy Research Working Paper 1293, World Bank, Washington, D.C. 
Hertel, T.W. (ed.) (1997), Global Trade Analysis Modeling and Applications (Cambridge University Press).

Huff, K. and T. W. Hertel (1996) Decomposing welfare changes in GTAP, GTAP Technical Paper No. 5 (Global Trade Analysis Project, Purdue University).

International Monetary Fund (1997) Morocco - Selected Issues, IMF Staff Country Report No. 97/6.

International Monetary Fund (2001) Morocco: 2001 Article IV Consultation, Staff Report. IMF Country Report No.01/205.

Jensen, P.E. and V. Madan (2004) Preferential Trade Agreements, Market Power, and Product Differentiation, Journal of Economic Integration 19(1): 162-181.

Johnson, J. (1960) Statistical Cost Analysis (McGraw Hill).

Malcolm, G. (1998) Adjusting Tax Rates in the GTAP Data Base, GTAP Technical Paper No. 12.

McQueen, M. (2002) The EU's Free-trade Agreements with Developing Countries: A Case of Wishful Thinking?, World Economy 25(9): 1369-1385.

Mayer, J. (2004) Export Dynamism and Market Access, Journal of Economic Integration 19(2): 289-316.

Mercenier, J. (1995) Can "1992" reduce unemployment in Europe? On welfare and employment of Europe's move to a single market, Journal of Policy Modeling 17(1): 1-37.

Nasr, H., L. Jaidi, and M. Zouaioui (1992) Prix et concurrence au Maroc: douze etudes sectorielles, Ministere Charge des Affaires Economiques (Ed. Najah El Jadida, Casablanca).

Panagariya, A. (2002) EU Preferential Trade Arrangements and Developing Countries, World Economy, 25, 10, 1415: 1432.

Panagariya, A. (2003) South Asia: Does Preferential Trade Liberalization Make Sense?, World Economy, 26, 9: 1279-1291.

Pratton C. (1988) A survey on the economies of scale, in Studies on the Economics of Integration, Luxemburg: Commission of the European Communities.

Rodrik, D. (1988) Imperfect competition, scale economies, and trade policy in developing countries, in Trade policy issues and empirical analysis, R.E. Baldwin, ed., Chicago, Illinois, University of Chicago Press.

Roland-Holst, D.W., K.A. Reinert and C.R. Shiells (1994) A general equilibrium analysis of North American economic integration, in Modeling Trade Policy: AGE Assessments of North American Free Trade, J.F. Francois and C.R. Shiells (eds.), (Cambridge: Cambridge University Press).

Rutherford T.F., E.E. Rutstrom and D. Tarr (1997) Morocco's free trade agreement with the European Community: A quantitative assessment, Economic Modeling 14: 237-269.

Smith, A. and A. J. Venables (1988) Completing the internal market in the European Community, European Economic Review, 32: 1502-1525.

Tangermann, S. (1997) Access to European Union markets for agricultural products after the Uruguay Round, and export interests of the Mediterranean countries, UNCTAD 
INT/93/A34

Willenbockell, D. (1994) Applied general equilibrium modeling: Imperfect competition and European integration (John Wiley \& Sons).

Willenbockell, D. (2002) Specification Choice and Robustness in CGE Trade Policy Analysis with Imperfect Competition, paper presented at the International Conference on Policy Modeling, Brussels, July 4-6, 2002.

World Bank (1994) Kingdom of Morocco - Republic of Tunisia; export growth: determinants and prospects, Washington DC, World Bank. 